\title{
NANOTUBULAR ALUMINOSILICATES: A CASE STUDY FOR SCIENCE AND INDUSTRY
}

\author{
NICOLÁS ARANCIBIA-MIRANDA ${ }^{a, b^{*}}$, SEBASTIÁN LILLO', MAURICIO ESCUDEYa,b
}

\begin{abstract}
${ }^{a}$ Center for the Development of Nanoscience and Nanotechnology, CEDENNA, 9170124, Santiago, Chile. NicolásArancibia-Miranda is corresponding author.
${ }^{b}$ Facultad de Química y Biología, Universidad de Santiago de Chile, Av. B. O'Higgins, 3363, Santiago, Chile.

'Vicerrectoría de Investigación Desarrollo e Innovación, Universidad de Santiago de Chile, Av. B. O'Higgins, 3363, Santiago, Chile.
\end{abstract}

(Received: July 30, 2013 - Accepted: November 18, 2013)

\begin{abstract}
The renewed interest in imogolite nanotubes, with structural similarities with carbon nanotubes (CNTs), has led to a new search of the potential of imogolite in the field of nanoscience. The applications of imogolite started being studied at the beginning of the 1970s, but the lack of technological development prevented a detailed study of this aluminosilicate. Furthermore, the strong incursion CNTs, which show exceptional structural characteristics and physical properties, left imogolite as the subject of secondary studies and applications in nanotechnology. This review, revise the scientific interest on imogolite from its discovery until the present, showing the main areas of research and development for this nanotube from a nanotechnological point of view.
\end{abstract}

Keyword: Imogolite, nanoparticle, nanotechnology, volcanic ash soil, adsorption, surface phenomena.

\section{INTRODUCTION}

The imogolite is a typical clay soils of volcanic origin and was discovered by Yoshinaga and Aomine in 1962 in soils derived from vitreous volcanic ash as Andosols and in the B horizon of Spodosols worldwide'. It is characterized for being a meta-stable state of kaolinite and its predominance depended of factors as temperature, relative humidity, salts concentration, and silica ratio present in the soil ${ }^{2,3}$. Ten years later from its discovery, Cradwick, et al., 1972, through a detailed XRD analysis, determined imogolite stoichiometry as $(\mathrm{OH})_{3} \mathrm{Al}_{2} \mathrm{O}_{3} \mathrm{SiOH}^{4}$. The imogolite is characterized as a nanotubular structure with an internal diameter of $2.5 \mathrm{~nm}$ and a variable length ranging from $100 \mathrm{~nm}$ to several microns ${ }^{5-9}$ (see Figure 1a).

In the structure and surface features of imogolite highlights its spatial distribution, with three types of pores (see Figure 1b), the intra-unit (A), inter-unit (B) and inter-fibrillar (C) ${ }^{10}$. Also has two types of surfaces, an outer surface dominated by aluminol groups $\left(\equiv \mathrm{Al}_{2}-\mathrm{OH}, \equiv \mathrm{Al}-\mathrm{OH}\right)$ (see Figure $\left.1 \mathrm{~b}\right)$, which are positively charged over a wide $\mathrm{pH}$ range (3.0-10.5) and an inner surface formed by silanol groups ( $\equiv \mathrm{Si}-\mathrm{OH})$ which is preferably negatively charged ${ }^{11-17}$.
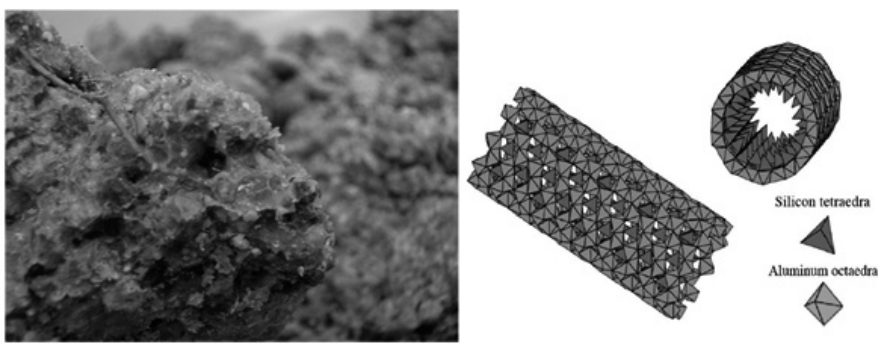

Figure 1.Picture of natural imogolite films in soil (left). Schematic representation of imogolite nanotube structure (right). Adapted from Ookawa 2012 and Levard, et al., 2009.

The formation of imogolite in the soil, involves complex reactions that begin with the total decomposition of primary silicate unit cells or dissolved ions. This decomposition is achieved through intense weathering (hydration, dissolution and hydrolysis), which form an ion-colloidal system, where coexist hydroxides of $\mathrm{Al}, \mathrm{Fe}$, and $\mathrm{Si}$ of variable composition ${ }^{5}$. These systems are oligopolymers and crosslinked polymers, which in the presence of low organic matter content of imogolite form, so that the increased presence of the aluminosilicate in the soil is deeper horizons $\mathbf{s}^{18,19}$.The imogolite formation in natural systems occurs in areas of greater soil depth, where the $\mathrm{Al} / \mathrm{Si}$ ratio, $\mathrm{pH}$ and lower concentration of organic matter favor the synthesis of imogolite ${ }^{20}$.

In the context of nanotechnology, the imogolite is projected as a nanoparticle with an enormous industrial potential due to their structural characteristics and unique physico-chemical properties. Its main applications have focused on its application as catalyst support, ion exchange, and adsorbent of gases. Its complex soil extraction and development of other nanostructures with similar functions, easier to obtain, discouraged the study of imogolite ${ }^{17,21-23}$.

Imogolite: The first synthetic inorganic nanotube?

The preparation of the first synthetic inorganic nanotube is usually assigned to Reshef Tenne ${ }^{22}$; however, in 1977 (15 years in advance), imogolite was synthesized by first time, by Colin Farmer from Macaulay Institute, being patented in $1981^{25}$. Later, Wada (1987) made some modifications in the temperature of procedure, to obtain a product closer to the natural one ${ }^{26}$, because of the proposed synthesis by Farmer and Fraser, produces imogolite of greater diameter and length than natural one ${ }^{25}$. It is important to emphasize that simplicity of imogolite synthesis, does possible to think about production at industrial level, but disadvantages existing in process have relation with temporary factors and yield, because is necessary between 1 to 3 days if synthesis is carried out at $100^{\circ} \mathrm{C}$ and 20 days at $60^{\circ} \mathrm{C}$, avoiding the presence of salts, since they favor the formation of allophane or protoimogolite ${ }^{27-29}$

In general, synthesis of imogolite consists of a first stage of acid hydrolysis of $\mathrm{Si}$ and $\mathrm{Al}$ precursors and subsequent polymerization, performed at 95 ${ }^{\circ} \mathrm{C}$ for approximately 5 days, resulting in a the tubular structure, similar to product in the soil ${ }^{26}$.A detailed study by Mukherjee et al., established that the synthesis of imogolite is developed in 5 basic steps ${ }^{29-31}$. Step I. Hydrolysis of the precursors at $\mathrm{mM}$ concentrations. Step II. Precursors basification to $\mathrm{pH} 5$ by addition of $\mathrm{NaOH}$. Step III. Partial re-acidification of the solution to $\mathrm{pH}$ 4.5. Step IV. Establishing of equilibrium conditions. Step V. Polymerization or aging. (Figure 2)

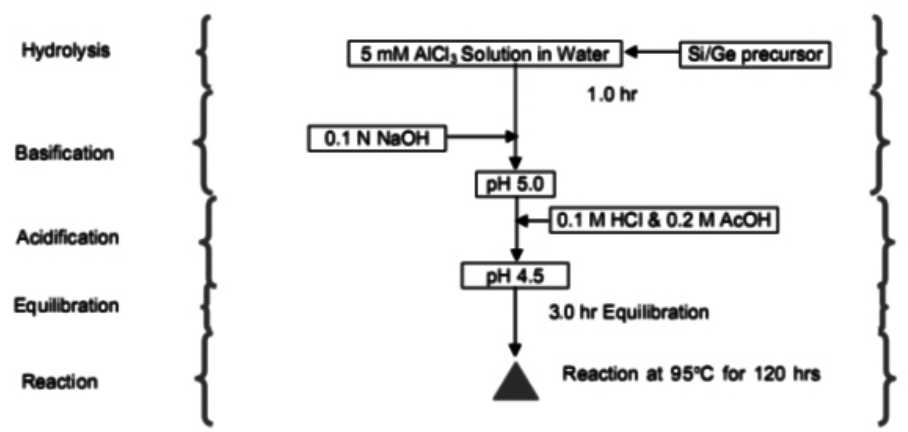

Figure 2. Aluminosilicate/Aluminogermanate nanotube synthesis process.

The temperature is one of the most important factors in the imogolite kinetic synthesis. It has been established that kinetic of growth reaches its maximum over $90^{\circ} \mathrm{C}$, were about 5 days are needed; when the aging is carried out at $60{ }^{\circ} \mathrm{C}$ imogolite fibers form after 20 days, and at $25{ }^{\circ} \mathrm{C}$ the process takes about 7 years ${ }^{26,29-32}$. Chemicals concentration and mixing rate are critical; thus, an increase in the $\mathrm{Al} / \mathrm{Si}$ ratio above 2.0, favors the tendency to form bohemite, whereas a high rate of addition of $\mathrm{NaOH}$ generates bayerite ${ }^{33}$. 
Characterization: Infrared spectroscopy, XRD, Microscopy (TEM, AFM, SEM), and isoelectric point.

Infrared spectroscopy /IR) and X-ray diffraction (XRD) are the fastest and most usual characterization methods used to establish the presence of synthetic imogolite. Farmer et al., 1977 established the most characteristic IR imogolite absorption band located at $348 \mathrm{~cm}^{-1}$ and assigned to Si-O stretching ${ }^{34}$.
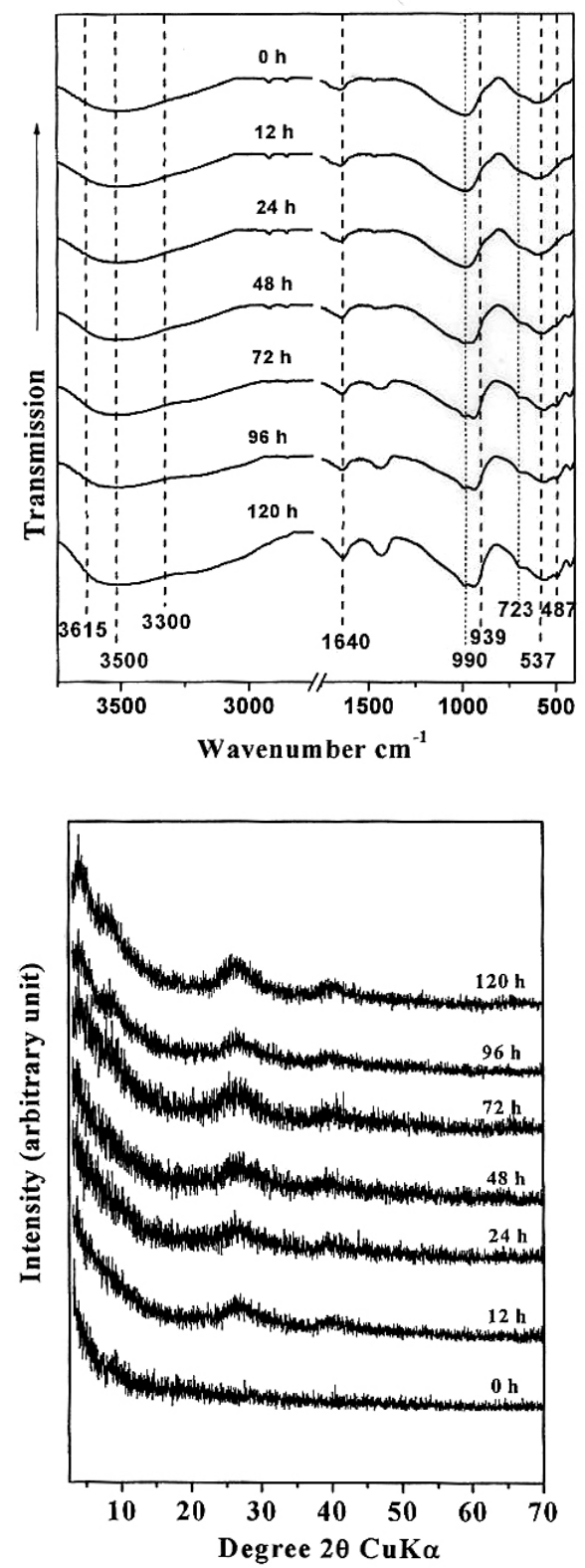

Figure 3. FTIR spectra (left) and XRD patterns (rigth) of the synthetic products at different aging times: (a) $0 \mathrm{~h}$, (b) $12 \mathrm{~h}$, (c) $24 \mathrm{~h}$, (d) $48 \mathrm{~h}$, (e) $72 \mathrm{~h}$, (f) $96 \mathrm{~h}$, and (g) $120 \mathrm{~h}$. Adapted from Arancibia-Miranda et al., 2013

Figure 3 shows other IR imogolite absorption signals located at 428, 506, 577 , and $967 \mathrm{~cm}^{-1}$; in addition, close to $3500 \mathrm{~cm}^{-1}$ a band associated to $-\mathrm{OH}$ stretching can be observed. In general terms, imogolite IR spectra are more acute tan theses of allophane being the doublet at 577 and $967 \mathrm{~cm}^{-1}$ the most significant difference (see Figure 3, left) ${ }^{12,34,35}$.

The XRD studies allow to establish a type $\mathrm{C} 2 \infty$ or $\mathrm{C} 2 \mathrm{n}$ tubular ordering. The presence and intensity of XRD peaks of this nanotube are close related to the condition of sample ${ }^{35,36}$. The shape and intensity of the first peak (at $20 \mathrm{~nm}$ ) are always related to the external diameter and the tubular structure characteristic peaks $(\mathrm{d}=2.00,0.90,0.63$ and $0.39 \mathrm{~nm})$, are assigned to $(010),(020),(030)$, and (032), respectively ${ }^{4}$ (see Figure 3, right). However, IR and XRD result in identification uncertainty related to the presence of imogolite because during aging process proto-imogolite is formed which is hard to differentiate from imogolite through IR and XRD, signals considering that both aluminosilicates have the same functional groups and similar crystalline ordering $11,12,35$.

Different electronic microscopy techniques facilitate the identification and characterization of imogolite, helping in the determination of its dimension and aggregate conditions. Transmission electronic microscopy (TEM) has allowed a more precise identification of imogolite since its discovery in the imogo soils in Japan $1,34,37,38$. From theses analysis the diameter and length of imogolite nanotubes has been established.
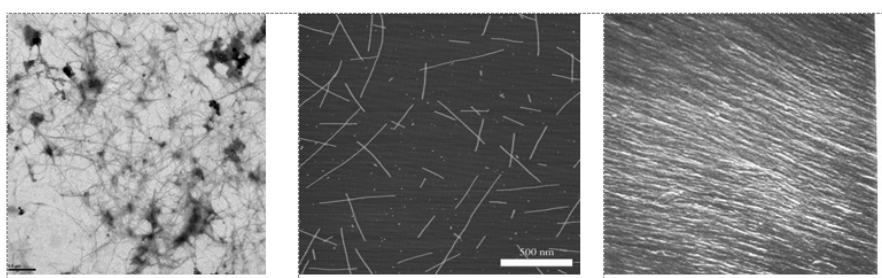

Figure 4. a) TEM (this work), b) AFM, (Ookawa, 2012) c) SEM of synthetic imogolite (Ackerman, et al., 1993).

However, scanning electronic microscopy (SEM) and atomic force microscopy (AFM) have been also used (see Figure 4). The SEM allowed to establish the presence of imogolite and its aggregation condition in different soils ${ }^{7,10}$, while AFM was used to characterize the imogolite nanotube diameter, ranging from 10 to $15 \mathrm{~nm}, 3$ to 6 times wider than those estimated from TEM studies 39,40 .

The surface and structural changes as consequence of the aging process can be detected through surface charge measurements carried out by electrophoretic migration (ME) ${ }^{11,41}$, which allows the determination of the isoelectric point (IEP) of samples. The IEP changes during the synthesis and aging processes, allowing identifying the product changes while reaction takes place ${ }^{11,12}$. In the case of imogolite, the results indicate that IEP changes can be associated to surface changes during its formation. In early stages of imogolite synthesis the IEP of the amorphous solid present similar amount of $\equiv \mathrm{Si}-\mathrm{OH}$ and $\equiv \mathrm{Al}-\mathrm{OH}$ active sites, resulting in low IEP values ${ }^{42}$.

During the aging process the originally flat surface become curved (tile shaped structure) as a consequence of restructuring of $\equiv \mathrm{Si}-\mathrm{OH}$ and $\equiv \mathrm{Al}-\mathrm{OH}$ groups, changing the $\mathrm{Al}-\mathrm{Si}$ ratio at the external surface being now the $\equiv \mathrm{Si}-\mathrm{OH}$ groups mainly part of the inner surface and the $\equiv \mathrm{Al}-\mathrm{OH}$ mainly part of the external surface, resulting in a significant change of more than two $\mathrm{pH}$ units in the IEP of solid ${ }^{11,12}$.

The external active surface groups mostly define the observed and quantified surface charge through EM. Toward the end of the aging process the final morphology is tubular, showing unusually high IEP values for an aluminosilicates which can be explained only if a total dominance of $\equiv \mathrm{Al}-\mathrm{OH}$ on the external surface of imogolite is considered, in addition to a slight structural charge of imogolite ${ }^{11-13}$.

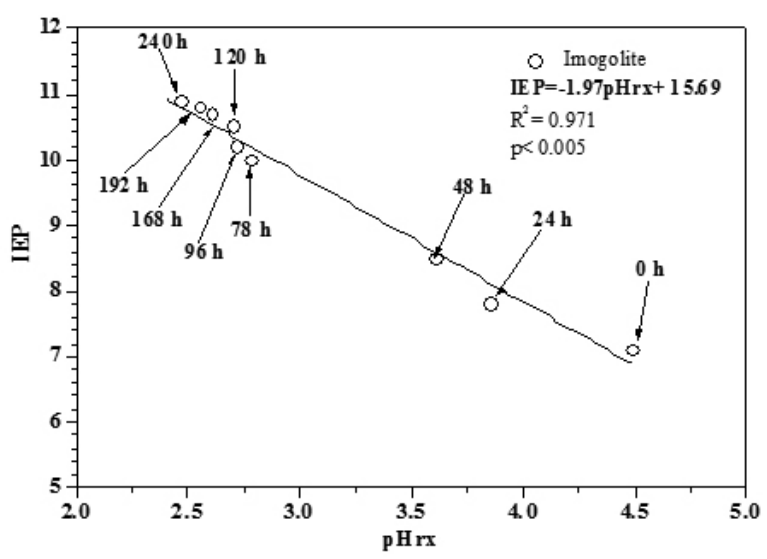

Figure 5. Relationship between isoelectric point (IEP) and reaction $\mathrm{pH}$ (pHrx) as a function of synthesis time. 
It has been demonstrated that equilibrium $\mathrm{pH}$ and IEP during synthesis and aging processes present a highly significant linear correlation as IEP= $-1.97 *(p H r x)+15.69$, giving a very simple tool for characterization and identification of imogolite ${ }^{11}$.

Imogolite formation mechanism

New imogolite synthetic processes have been of interest considering the potential applications of these nanostructures in areas such as nanotechnology $22,23,43-45$

In addition to IR, XRD, TEM, SEM, and AFM, the formation and characterization of imogolite has been studied by techniques such as FTIR spectroscopy, X-ray absorption spectroscopy (XAS), nuclear magnetic resonance (NMR), electrospray ionization mass spectrometry (ESI-MS), and small-angle X-ray scattering (SAXS) ${ }^{46,47}$. However, the experimental conditions of the synthesis and the particular limitations of each characterization technique have hindered the elucidation of the growth mechanism for this aluminosilicate. Research on structures analogous to imogolite, such as aluminogermanates $\left((\mathrm{OH})_{3} \mathrm{Al}_{2} \mathrm{O}_{3} \mathrm{GeOH}\right)$ have led to significant progress on a proposal for a general mechanism that explains the formation of imogolite $11,46,47$.

Recent publications pointed out on two critical factors in imogolite synthesis: concentration of the reagents in solution at the beginning of the synthesis (which must have an $\mathrm{Al} / \mathrm{Si}$ ratio of 2 and must be in the order of $\mathrm{mM}$ ) and temperature (which determines the formation kinetic of the nanoparticles) ${ }^{12,26,46 \text {, }}$

${ }^{47}$. These factors play an important role in the growth, dissolution, aggregation, and aging of imogolite.

The first stage is the formation of precursors that will evolve into imogolite, and, according to Maillet et al., they correspond to short-range amorphous sub-nanometric species. However, according to Yucelen et al., the precursors formed are of Keggin-ion type, and both precursors originate from the hydrolysis of the starting reagents ${ }^{46,47}$.

The growth and development of these precursors into more complex structures (i.e., raft and ring structures) occurs through a self-assembly mechanism that originates during Ostwald ripening ${ }^{48-50}$, a process associated with reactions that involve thermal aging, such as the case of imogolite synthesis ${ }^{12,46,47}$. These processes are those that result in the most significant changes in the precursors at the structural and surface level, as indicated by the IEP and equilibrium $\mathrm{pH}$ values (see Figure 5)

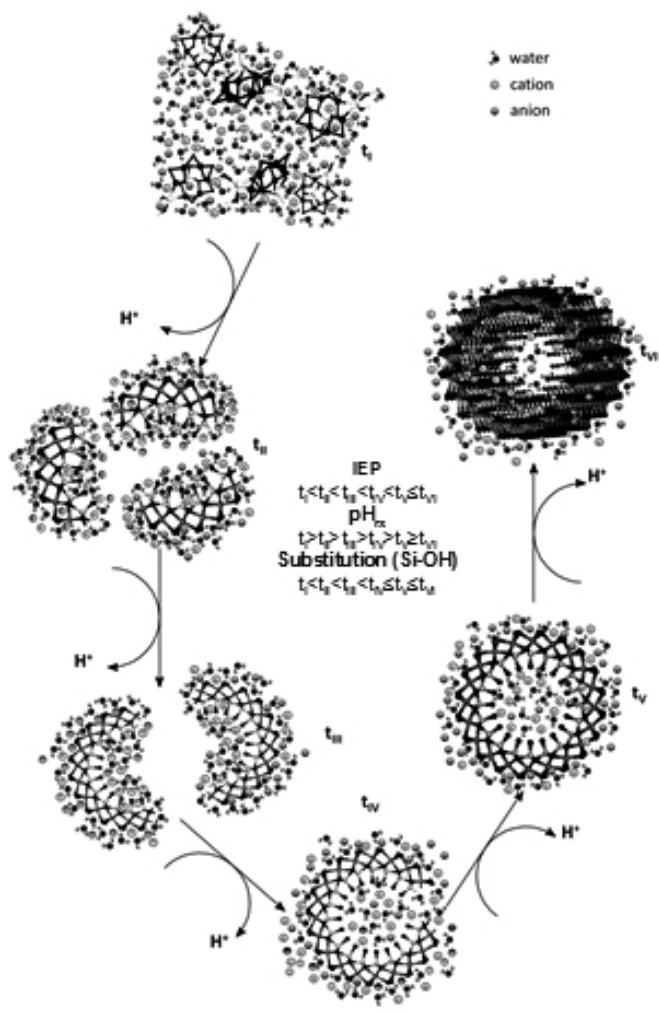

Figure 6. Structural evolution of the precursors formed during the synthesis of imogolite. (Adapted from Arancibia-Miranda et al., 2013).
Independently of the specific mechanism through which imogolite is obtained ${ }^{30,46,47}$, it should be stressed that the magnitude of the structural changes and the marked differences in the chemical reactivity of the groups that are formed during the aging process $\left(\equiv \mathrm{Al}_{2}-\mathrm{OH}, \equiv \mathrm{Al}-\mathrm{OH}\right.$ and $\left.\equiv \mathrm{Si}-\mathrm{OH}\right)$, allow the use of surface characterization techniques like electrophoretic migration (EM). The high sensitivity of EM technique to small surface changes allows the evolution of the precursors and their later assembly and growth to be followed ${ }^{41}$. The linear relationship between IEP and equilibrium $\mathrm{pH}$ previously described, can be used to follow the synthesis and aging process ${ }^{11}$.

Table 1. Isoelectric point (IEP), reaction $\mathrm{pH}\left(\mathrm{pH}_{\mathrm{rx}}\right), \Delta \mathrm{IEP} / \Delta \mathrm{t}$, and $\Delta \mathrm{pH}_{\mathrm{rx}} / \Delta \mathrm{t}$ as a function of the synthesis time.

\begin{tabular}{|c|c|c|c|c|}
\hline Time (h) & IEP & $\Delta \mathbf{I E P} / \Delta \mathbf{t}$ & $\mathbf{p H}_{\mathbf{r x}}$ & $\Delta \mathbf{p H}_{\mathbf{r x}} / \Delta \mathbf{t}$ \\
\hline 0 & $6.6 \mathrm{a}$ & 0 & $4.49 \mathrm{a}$ & 0 \\
\hline 12 & $7.1 \mathrm{~b}$ & 4.2 & $4.26 \mathrm{~b}$ & 1.90 \\
\hline 24 & $7.8 \mathrm{c}$ & 5.8 & $3.85 \mathrm{c}$ & 3.40 \\
\hline 48 & $8.5 \mathrm{~d}$ & 2.9 & $3.61 \mathrm{~d}$ & 1.80 \\
\hline 72 & $10.0 \mathrm{e}$ & 6.3 & $2.78 \mathrm{e}$ & 3.50 \\
\hline 96 & $10.3 \mathrm{ef}$ & 1.3 & $2.72 \mathrm{f}$ & 0.03 \\
\hline 120 & $10.6 \mathrm{fg}$ & 1.3 & $2.70 \mathrm{fg}$ & 0.01 \\
\hline
\end{tabular}

Within columns, values followed by the same letter are not significantly different according to Tukey's test $(\mathrm{p}<0.01)$. The $\Delta \mathrm{IEP} / \Delta \mathrm{t}$ and $\Delta \mathrm{pH}_{\mathrm{r} x} / \Delta \mathrm{t}$ values are amplified by a factor of 10 .

While IEP values increases the $\mathrm{pH}$ of the reaction decreases with the evolution and condensation of the precursors during aging. Integration of all the results obtained the structural and surface characterization allows an overall understanding of the different processes that occur and the products that are formed during the synthesis of imogolite. A more significant way of observing the effect of structural changes on reaction $\mathrm{pH}$ is to represent the variation of this parameter as a function of aging time (see Table 1 and Figure 7$)^{11,12}$.
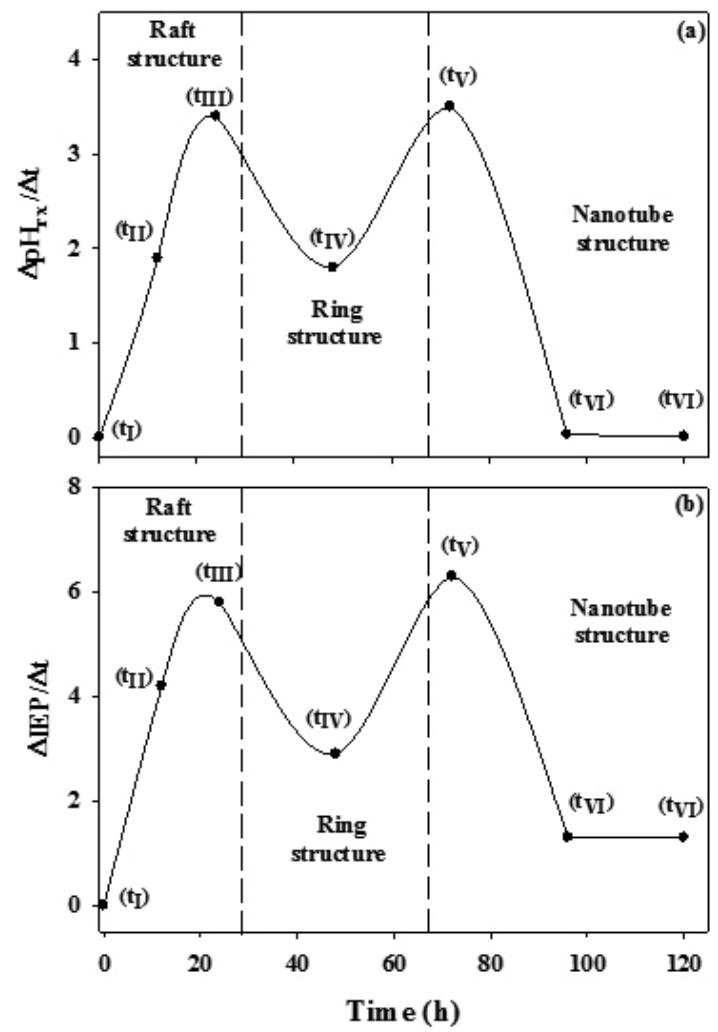

Figure 7. Changes with time of reaction $\mathrm{pH}\left(\Delta \mathrm{pH}_{\mathrm{rx}} / \Delta \mathrm{t}\right)$ and isoelectric point $(\Delta \mathrm{IEP} / \Delta \mathrm{t}$ ), as a function of aging time. (Adapted from Arancibia-Miranda et al., 2013). 
This graph shows clearly that the most significant structural changes result in the most important variation of $\mathrm{pH}$. It is seen that three important variations occur: the first is that from the monomeric and oligomeric precursors $\left(t_{t}\right.$, Figure 6 ) to the raft type structure ( $t_{\text {III }}$, Figure 6 ); the second corresponds to the path from the raft type structures to rings ( $\mathrm{t}_{\mathrm{III}} \rightarrow \mathrm{t}_{\mathrm{V}}$, Figure 6); and the third accounts for the one-dimensional growth of the ring-type structure until it forms the imogolite nanotube $\left(\mathrm{t}_{\mathrm{v}} \rightarrow \mathrm{t}_{\mathrm{v}}\right.$, Figure 6). A similar association can be made when the change in the IEP as a function of the change of time $(\Delta \mathrm{IEP} / \Delta \mathrm{t})$ is evaluated (see Figure 6) ${ }^{12}$

\section{Imogolite and its potential in nanotechnology}

From the perspective of nanotechnology, its structure, physical, and chemical properties and high flexibility to achieve surface modifications, position the imogolite as an excellent candidate for nanotechnology applications ${ }^{6,22}$ ${ }^{51-55}$. One of the first modifications was proposed by Wada and Wada (1982), consisting of partial substitution of $\mathrm{Si}$ by $\mathrm{Ge}$, forming aluminogermanates, which have a diameter of $3.3 \mathrm{~nm}, 50 \%$ wider than that determined for imogolite, while its length is $15 \mathrm{~nm}, 7$ times shorter than that obtained for imogolite 10, 30, 38, 56. Further research on these aluminogermanates indicates that this type of nanotube formation processes are faster and their packing is monoclinic and hexagonal as imogolite ${ }^{30}$. Its applications have focused on the possibility of developing biodevices able to detect biomolecules such as DNA, functioning as nanowires ${ }^{53,57}$.

Different theoretical studies estimated that the band gap of these aluminosilicates can vary between 3.67 to $10 \mathrm{ev}$, depending on the calculation method used, which suggests that imogolite has insulating properties as semiconductor 7, 53,57. In a recent research Kuc and Heine (2009) raised the idea of a coaxial nanowire carbon nanotube (CNT) coated with an insulating sheath made of imogolite, which would broaden the scope of this nanomaterial to be used in nanoelectronic devices (see Figure 8$)^{54}$
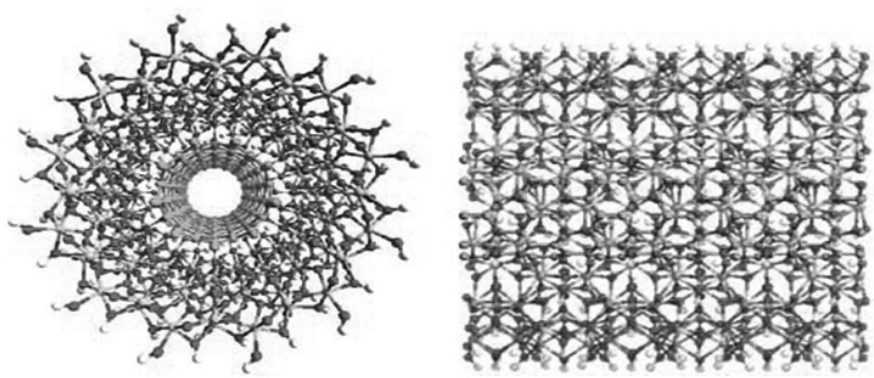

Figure 8: Schematic representation of a nanowire formed by CNT@imogolite (Adapted from Kuc and Heine, 2009).

In terms of nanotechnological applications of aluminogermanates, there is no experimental evidence to clarify how the $\mathrm{Si}$ and $\mathrm{Ge}$ atoms locate themselves in the unit cell. The addition of $\mathrm{Fe}$ (III) replacing structurally $\mathrm{Al}^{3+}$, is another of the changes that have taken place in the synthesis of imogolite ${ }^{58-60}$. This change results in a functionalized imogolite which can be used to catalyze different reactions, mainly in the oxidation of organic compounds such as cyclohexane, toluene, benzaldehyde, and chlorobenzenes, generating epoxy derivatives, ketones and alcohols, highlighting the conversion of benzene to phenol. ${ }^{59,60}$.

Other imogolite surface-level alternative is the substitution of $\mathrm{OH}$ functional groups. The imogolite can exchange one or more hydroxyl belonging to $\equiv \mathrm{Al}-\mathrm{OH}$ groups, for molecules derived from alkyl phosphonic acids, giving products with different optical and electrical properties related to the starting materials ${ }^{61-65}$.

The use of imogolite as a support in nanohybrids has been an important development in the field of physics, because it strengthens the conductive properties of light and electricity, and the mechanical and optical properties of organic polymers as a consequence of birefringence, which is a very important phenomenon in the use of optical fibers (see Figure 6) ${ }^{61,66}$.

Recently, Geraldo et al. (2012) used single-imogolite as a one-dimensional template for the in situ growth of mercaptopropionic acid-capped CdTe quantum dots (QDs). This new nanohybrid hydrogel was synthesized by a simple reaction pathway and their enhanced optical properties were monitored by fluorescence and UV-Vis spectroscopy, confirming that the use of these nanotubes favors the confinement effects of net CdTe QDs. In addition, studies of FT-IR spectroscopy and transmission electron microscopy confirmed the non-cova- lent functionalization of imogolite. Finally, the antimicrobial activity of imogolite coated with CdTe QDs toward three opportunistic multi-resistant pathogens such asSalmonellatyphimurium, Acinetobacterbaumannii, and Pseudomonas aeruginosawere tested. Growth inhibition tests were conducted by exposing growing bacteria to CdTe QDs/ imogolite hybrid compound, showing that the new nano-structured composite is a potential antimicrobial agent for heavy metal-resistant bacteria ${ }^{22}$.

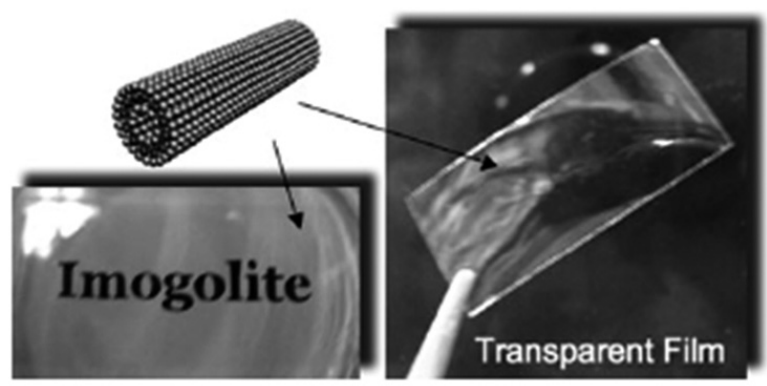

Figure 9. Picture of imogolite/poly (vinyl alcohol) (PVA). The incorporation of imogolite improves the mechanical and optical properties of PVA (Adapted from Yamamoto et al., 2001, 2005a, 2005b, 2007).

Studies carried out by culture in vitro to determine the compatibility of the imogolite with biological systems, suggests that this nanoparticle does not cause toxicity in cells that constitute the immune system; additionally, imogolite was able to form a complex with yeast RNA, attenuating tumor cells ${ }^{67}$, ${ }^{68}$. Ishikawa et al. (2010), reported that the presence of imogolite in cultured bone cells increases osteoblastic activity, which opens potential uses of this nanoparticle to help in the generation of this type of tissue damaged by fractures. The use of nanoparticles and specifically of imogolite, in these types of applications, still requires more specific research, before get the real dimension of its potential ${ }^{69}$.

The imogolite in the scientific community

To overview the interest of the scientific community and its development with time, a bibliometric imogolite analysis since 1998 was carried out. The analysis considers all the articles indexed in the Web of Knowledge-ISI data base. To collect them, all the articles involving the keyword "imogolite" in title, abstract or as keyword set were considered. Under those criteria 450 items were found and analyzed.

\section{Papers per year Indexed in the Web of Knowledge Data Base}

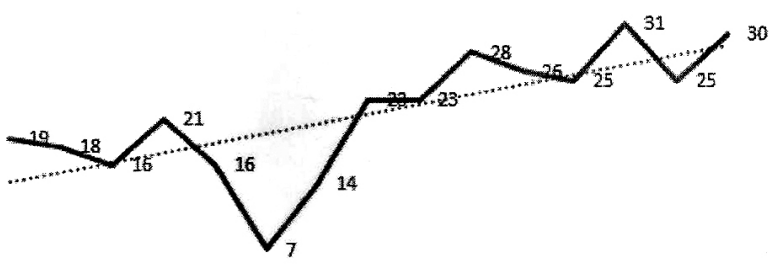

199819992000200120022003200420052006200720082009201020112012

Figure10. Publication rate at the Web of Knowledge-ISI data base including "imogolite" keyword since 1998.

As observed in Figure 10, in 2012 the highest publication intensity was reached, with 31 papers but with a regular growing tendency on the time since 2005. In relation with publication areas, the most significant figures involve Soil Science (mainly since 1998 to 2005), Physical-chemistry, and Material Sciences. Very often publications are categorized as "multidisciplinary", and Materials Science classification is the most significant (38\%) in the last three years. When publication network in the last three years is analyzed, Japan, France and USA are the countries with more interest in synthesis, functionalization, technological application, and properties of imogolite nanotubes. 


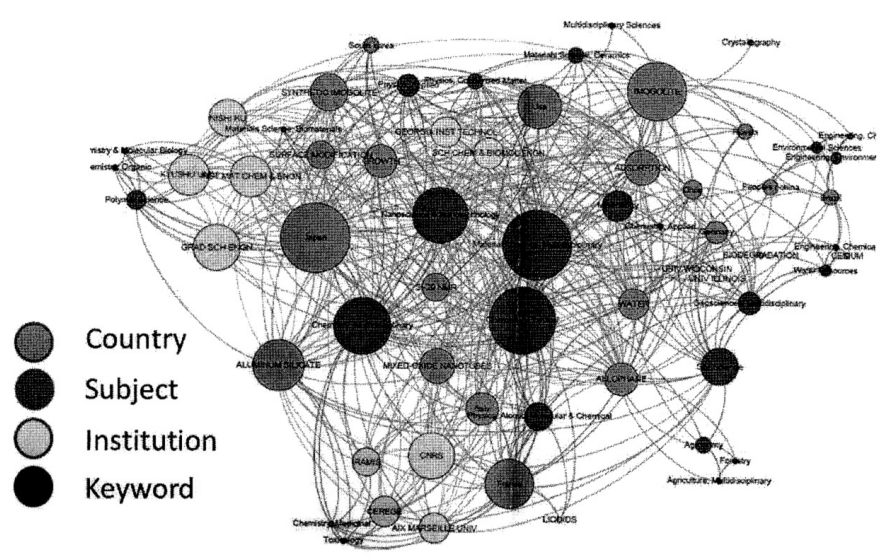

Figure 11. Publication network distribution, considering Subject (Science area) country, keyword and institution.

\section{CONCLUSIONS}

The surface behavior of imogolite, their nanoscale dimensions, high surface area, and its synthesis greatly developed, allow to project this aluminosilicate, as a nanoparticle that meets several requirements for use in the field of nanotechnology, which has had interesting results, mainly due to:

- The high flexibility of structural and active surface sites modifications: It is possible to synthesize imogolite with different elements mainly $\mathrm{Fe}, \mathrm{Ge}$ or modify it with alkyl phosphonic acids, enhancing the qualities of this aluminosilicate and multiplying its functions. Applications to oxidation of organic compoundsand its electrical, optical, mechanical and magnetic properties, open up a huge potential for application in priority areas of science such as biotechnology and nanotechnology.

- The broader nanotechnology field and the lack of information on studies of imogolite in many areas, the low requirements in infrastructure and its unlimited projections, positioning this nanoparticle in a future, advanced stalls in nanoscience and nanotechnology.

\section{REFERENCES}

1. N. Yoshinaga, S. Aomine, Soil. Sci. Plant. Nutr.8, 22, (1962).

2. V.C. Farmer, J.D. Russell, M.L.Berrow, J. Soil Sci. 31, 673, (1980).

3. S. Konduri, S. Mukherjee, S. Nair. Phys. Rev. B.74, 1 (2006).

4. P.D.G. Cradwick, , V.C. Farmer, J.D. Russell, C.R. Masson, K. Wada, N. Yoshinaga, Nat. Phys. Sci.240, 187, (1972).

5. E. Besoain. Mineralogías de Arcillas de Suelos, Instituto Interamericano de cooperación para la Agricultura, San José, Costa Rica,1985

6. V.C. Farmer, M.J. Adams, A.R. Fraser F.Palmieri.Clay Minerals.18, 459,(1983).

7. Z. Abidin, T. Henmi, Jpn. J. Appl. Phys.47, 5079 (2008).

8. C. Levard, A.Masion, J. Rose, E.Doelsch, D.Borschneck, C.Dominici, F.Ziarelli, J.Y.Bottero, J. Am. Chem. Soc.131, 17080 (2009).

9. M. Ookawa, Synthesis and Characterization of Fe-Imogolite as an Oxidation Catalyst. Clay Minerals in Nature - Their Characterization, Modification and Application. DOI: 10.5772/2708.

10. W.C Ackerman, D.M. Smith, J.C. Huling, Y-W. Kim, J.K Baileyg, C.J. Brinkertps, Langmuir.9, 1051, (1993).

11. N. Arancibia-Miranda, M.Escudey, M. Molina, M.T.García-González. J. Non-Cryst. Solids. 357, 1750, (2011).

12. N. Arancibia-Miranda, M.Escudey, M. Molina, M.T.García-González. Nanomaterial.3, 126, (2013).

13. M. Escudey, G. Galindo. Bol. Soc. Chil. Quim. 38, 227, (1993).

14. M. Escudey, G. Galindo. Bol. Soc. Chil. Quim. 39, 63, (1994).

15. J.P. Gustafsson, Clays Clay Miner. 49, 73, (2001).

16. J. Karube, K.Nakaishi, H. Sugimoto, M.Fujihira, M. Clays Clay Miner.40, $625,(1992)$.

17. C. Levard, E. Doelsch, J. Rose, A. Masion, I. Basile-Doelsch, O. Proux, J-L. Hazemann, D. Borschneck, J. Bottero, J. Geochim. Cosmochim. Acta. 73, 4750, (2009).

18. S. Aomine, C. Mizota, Distribution an genesis of imogolite in volcanic ash soils of norther Kanto, Japan [Abst.]: International Clay Confer- ence, Madrid, Spain, 103-104, 25-30 June (1972)

19. K. Inoue, P.M. Huang. Nature.308, 58, (1984).

20. F.C.Ugolini, R. Dahlgren, R. The mechanism of podzolization as revealed by soil solution studies. College of Forest Resources University of Washington, Seattle (1986).

21. V.C. Farmer, M.J. Adams, A.R. Fraser,F.Palmieri.Clay Miner. 18, 459 , (1983).

22. D.A. Geraldo, N. Arancibia-Miranda, N.A. Villagra, G.C. Mora, R. Arratia-Perez. J. Nanopart. Res.14, 1286, (2012).

23. S. Imamura, Y.Hayashi, K.Kajiwara, H.Hoshino, C.Kaito.Ind. Eng. Chem. Res. 32, 600, (1993).

24. R. Tenne, Nat. Nanotechnol.1, 103 (2006)

25. V.C.Farmer, Synthetic Imogolite, 4,252,779, Feb. 24, 1981, United States Patent, U.S.A.

26. S-I. Wada. Clays Clay Miner.35, 379 (1987).

27. V.C. Farmer, A.R. Fraser, J.M. Tait. J. Chem. Soc., Chem. Comm.13, 462, (1977)

28. Z. Abidin, N. Matsue, T. Henmi, J. Comput-Aided Mater. 14, 5, (2007)

29. S. Mukherjee, Synthesis, Characterization, and Growth Mechanism of Single-Walled Metal Oxide Nanotubes, Ph. D. thesis, Georgia Institute of Technology, Georgia, USA, 148 pp, (2007).

30. S. Mukherjee, V.A.Bartlow, S. Nair. Chem. Mater.17, 4900, (2005)

31. S. Mukherjee, K. Kim, S. Nair. J. Am. Chem. Soc. 21, 6820, (2007).

32. M. Suzuki, K.Inukai, M.Maeda, J. Vac. Soc. Jpn. 49, 29, (2005)

33. S.M Barrett, P.M. Budd, C. Price, Eur.Polym. J.27, 609, (1991)

34. V.C. Farmer, A.R. Fraser, J.D. Russell, N. Yoshinaga, Clay Miner.12, 55, (1977).

35. M.A. Wilson, G.S.H. Lee, R.C. Taylor, J. Non-Cryst. Solids.296, 172, (2001).

36. C. Levard, J. Rose, A. Thill, A. Masion, E.Doelsch, P.Maillet, O.Spalla, L.Olivi, A. Cognigni, F.Ziarelli, J.Y. Bottero,Chem. Mater.22, 2466, (2010).

37. S. Aomine, N. Miyauchi, Soil Sci. Plant Nut. 11, 212, (1962)

38. S-I. Wada, K. Wada, Clays Clay Miner.30, 123, (1982).

39. Y. Ohrai, T. Gozu, S. Yoshida, O.Takeuchi,S.Iijima, H.Shigekawa, Jpn. J. Appl. Phys. 44, 5397, (2005).

40. N. Jiravanichanun, K. Yamamoto, A.Irie, H.Otsukaa, A.Takahara, Synt. Met.159, 885,(2009).

41. F.J. Gil-Llambías, A.M.Escudey-Castro, J. Chem. Soc., Chem. Commun. 9, 478, (1982)

42. H. Tsuchida, S.Ooi, K.Nakaishi, Y. Adachi, Colloid Surf.265, 131, (2005).

43. G. Yuan, J. Environ. Sci. Health.39, 2545, (2004).

44. X. Qi, H. Yoon, S.H. Lee, J. Yoon, S.J. Kim, J. Ind. Eng. Chem.14, $136,(2008)$.

45. B. Bonelli, I.Bottero, N.Ballarini, S.Passeri, F.Cavani, E.Garrone, $J$ Catal.264, 15, (2009).

46. G.I. Yucelen, R.Choudhury, A.Vyalikh, U.Scheler, H.W. Beckham, S. Nair, J. Am. Chem. Soc.133, 5397, (2011).

47. P. Maillet, C. Levard, O. Spalla, A. Masion, J. Rose, A. Thill, Phys Chem. Chem. Phys. 13, 2682, (2011).

48. B.P. Singh, R.Menchavez, C.Takai, M. Fuji, M. Takahashi, J. Colloid Interf. Sci. 291, 181, (2005).

49. C.I. Steefel, P. Van Cappellen, K.L. Nagy, A.C.Lasaga, Chem. Geol. 84, 322, (1990).

50. C.J. Brinker, G.W. Scherer, Sol-gel science, in: The Physics and Chemistry of Sol-Gel Processing, Harcourt Bace Jovanovich, Boston, MA. (1989).

51. V.C. Farmer, A.R. Fraser, J.M. Tait, F. Palmieri, P. Violante, M. Nakai, N. Yoshinaga, Clay Miner. 13,274, (1978).

52. L.A. Bursill, J.L. Peng, L.N. Bourgeois, Philos. Mag. A. 80,117, (2000).

53. F. Alvarez-Ramirez, Phys. Rev. B. 76, 14, (2007).

54. A. Kuc, T. Heine, Adv. Mat. 21, 4356, (2009).

55. W.O. Yah, K. Yamamoto, N. Jiravanichanun, H. Otsuka, A. Takahara, Mater. 3, 1745, (2010).

56. P.I. Pohl, J-L. Faulon, D.M. Smith, Langmuir. 12, 4468, (1996).

57. L. Guimarães, A. N. Enyashin, J. Frenzel, T. Heine, H. A. Duarte, G. Seifert, Acs Nano. 1, 368, (2007).

58. V. C. Farmer, A. R. Fraser, Synthetic imogolite, a tubular hydroxyaluminium silicate: in Proc. Int. Clay Conf., Oxford, M. M. Mortland and V. C. Farmer, eds., Elsevier, Amsterdam, (1978).

59. M. Ookawa, Y. Inoue, M. Watanabe, M. Suzuki, T. Yamaguchi, Clay Sci. 2, 284, (2006).

60. M. Ookawa, Y. Takata, M. Suzuki, K. Inukai, T. Maekawa, T. Yamaguchi, 
Res. on Chem. Intermediat. 4, 685, (2008).

61. K. Yamamoto, H. Otsuka, A. Takahara, Polim. J.39, 15, (2007).

62. K. Yamamoto, H. Otsuka, S-I. Wada, A. Takahara, Chem. Lett. 30, 1169 , (2001).

63. K. Yamamoto, H. Otsuka, S-I. Wada, D. Sohn, A. Takahara, Soft Matter, 1, 377, (2005)

64. K. Yamamoto, H. Otsuka, S-I. Wada, D. Sohn, A. Takahara, Polymer, 46, 12392, (2005)
65. Y. Kuroda, K. Kuroda, Sci. Technol. Adv. Mat. 9, 8, (2008).

66. M. Matsumoto, S. Koibuchi, N. Hayashi, Colloids Surfaces B.56, 113, (2007).

67. V.C. Farmer, B.F.L. Smith, J.M. Tait, Clay Miner. 14, 107, (1979).

68. K. Maekawa, A. Momii, P. Jpn. Acad. 48, 693, (1972).

69. K. Ishikawa, T. Akasaka, Y. Yawaka, F. Watari, J. Biomed. Nano. 6, 65, (2010). 